\title{
Vertical Specialization and the Changing Nature of World Trade
}

\section{David Hummels, Dana Rapoport, and Kei-Mu Yi}

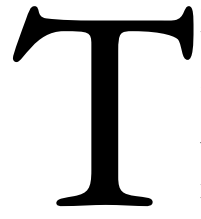

he world's economies have become increasingly integrated and increasingly global. Among the most important and often cited features of the rise in globalization is the enormous growth in the export and import shares of GDP since World War II. In the United States, international tradethat is, exports plus imports-accounted for 23.9 percent of GDP in 1996, up from 9.2 percent in $1962 .{ }^{1}$ Worldwide, the merchandise export share of production has more than doubled over the last forty-five years, while the manufactured export share of production has almost quadrupled (Chart 1). Most countries_emerging nations as well as highly developed economies - have experienced increases in their export share of GDP (Chart 2). Clearly, a greater number of countries are trading more today than in the past.

David Hummels is an assistant professor of economics at the University of Chicago's Graduate School of Business; Dana Rapoport is an assistant economist and Kei-Mu Yi an economist at the Federal Reserve Bank of New York.
Another significant feature of increased globalization is the internationalization of production. Rather than concentrate production in a single country, the modern multinational firm uses production plants-operated either as subsidiaries or through arm's-length relationships-in several countries. By doing so, firms can exploit powerful locational advantages, such as proximity to markets and access to relatively inexpensive labor. There are currently more than 39,000 parent firms and 279,000 foreign affiliates worldwide, with a total foreign direct investment (FDI) stock equal to $\$ 2.7$ trillion in 1995 , compared with $\$ 1.0$ trillion in 1987. Moreover, the value added of foreign affiliates - that is, their sales less materials costsaccounted for 6 percent of world GDP in 1991, a 300 percent increase from 1982 (United Nations Conference on Trade and Development 1996).

Increased international production, however, does not always lead to increased international trade. For instance, if a country's firms serve markets abroad through production facilities in each country-rather than through 
exports from the home country-trade may actually decrease as international production rises. International production will be associated with increased trade when countries are vertically linked-that is, when international production prompts countries to specialize in particular stages of a good's production. In that case, a sequential mode of production arises in which a country imports a good from another country, uses that good as an input in the production of its own good, and then exports its good to the next country; the sequence ends when the final good reaches its final destination. We use the term "vertical specialization" to describe this mode of production. ${ }^{2}$ By comparison, in a horizontal-specialization scenario, countries trade goods that are produced from start to finish in just one country.

In this article, we shed light on the globalization of international production and trade by demonstrating the increasingly important role vertical specialization plays in international trade. We use case studies and

Chart 1

\section{World PRODUCTION AND EXPORT VOLUMES}

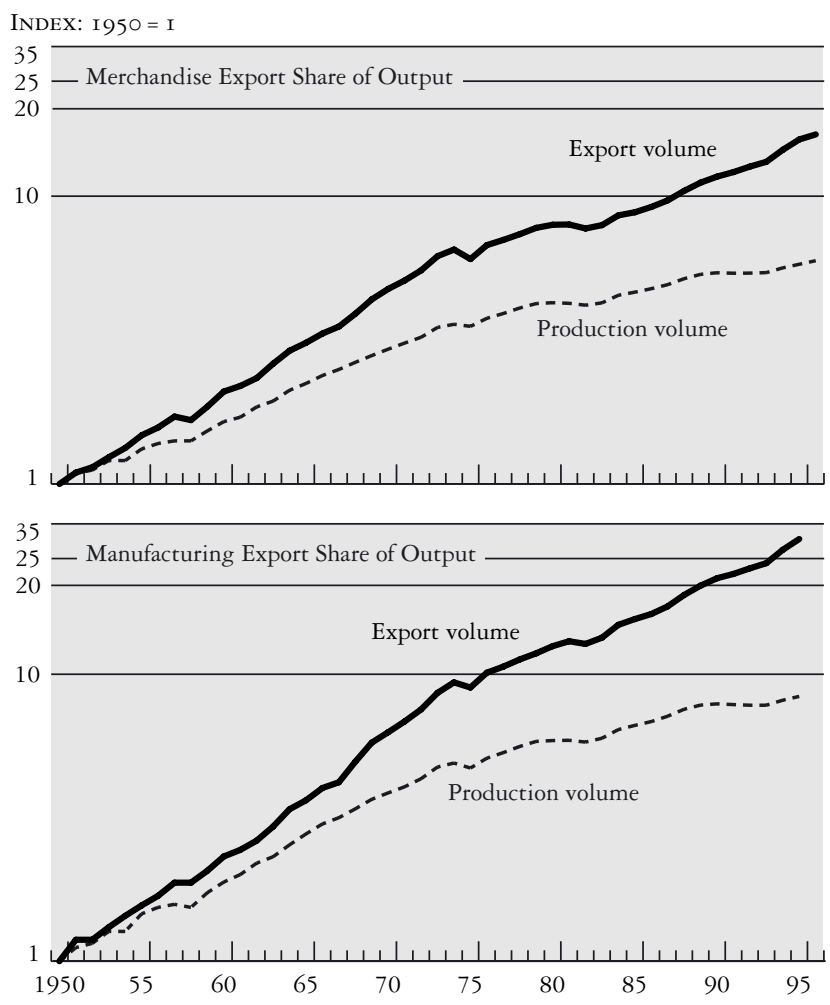

Source: World Trade Organization Secretariat. input-output tables to calculate the level and growth of vertical-specialization-based trade, which we define as the amount of imported inputs embodied in goods that are exported. The case studies-the United States-Canada Auto Agreement of 1965, Mexico's maquiladora trade with the United States, electronics trade between Japan and Asia, and trade involving Opel's subsidiary in Spainallow us to quantify the amount of vertical-specializationbased trade. ${ }^{3}$ In all of the case studies, our findings indicate that vertical specialization has increased sharply in recent years: in the Japan-Asia electronics trade, for example, it increased 900 percent between 1986 and 1995.

To show that the results of our case studies can be generalized, we use input-output tables to calculate estimates of vertical-specialization-based trade in ten developed countries from the Organization for Economic Cooperation and Development (OECD). We find that by the beginning of the present decade, 14.5 percent of all trade in these countries was vertical-specialization-based-a 20 percent increase

Chart 2

Countries' i962 AND i995 Export SHARES OF GDP:

Most Countries' Export SHares InCREASED

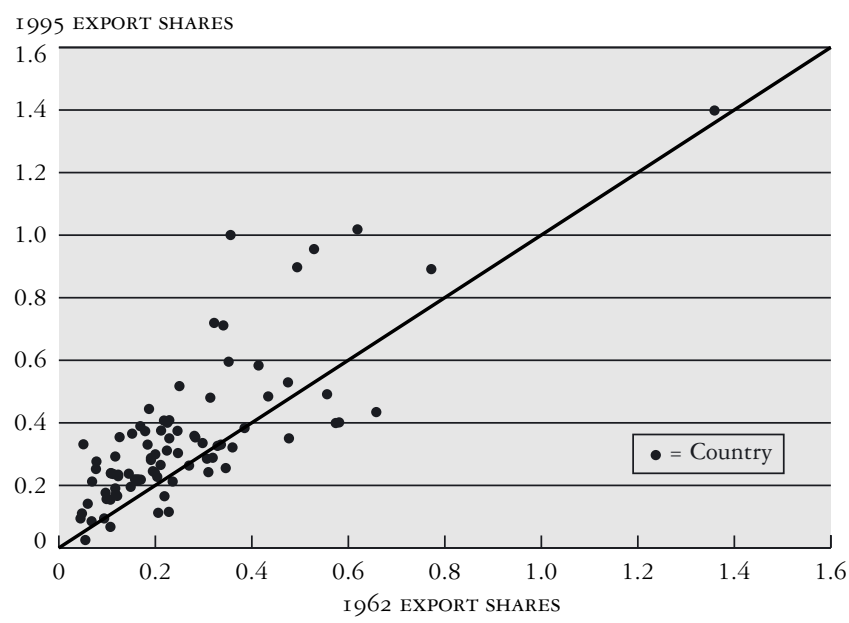

Source: Authors' calculations, based on data from International Monetary Fund, International Financial Statistics Yearbook.

Notes: Each dot represents a different country. If a country lies above and to the left of the $45^{\circ}$ line, then its 1995 export share is larger than its 1962 export share. It is clear that this is the case for a majority of the countries. Furthermore, this phenomenon is true for all types of countries: Countries as distinct as Bangladesh, the Congo, Germany, Ireland, Korea, Malaysia, and the United States all lie above the $45^{\circ}$ line. 
from the late 1960s and early 1970s. Thus, while the majority of trade continues to be horizontal, vertical-specializationbased trade is making significant gains.

Analysis of our OECD data reveals a strong statistical association between the increased vertical specialization share of total trade and the rising trade shares of GDP. In addition, it shows that the industries accounting for most of the increase in the vertical specialization share of total trade-chemicals, and machinery and equipment-also account for most of the increase in overall trade as a share of

\section{Vertical specialization occurs when a country}

uses imported intermediate parts to produce

goods it later exports. This definition captures

the idea that countries link sequentially to

produce a final good.

GDP. Increases in vertical-specialization-based trade are also found to account for more than 25 percent of the increase in total trade in most of our ten OECD countries.

Our study also considers some implications of the increase in vertical specialization for trade policy. Although a detailed examination of policy issues is beyond the scope of this article, our results lead to two tentative conclusions. First, even though tariff and nontariff barriers worldwide are now quite low, especially among the developed countries, vertical specialization can magnify the gains that are achieved by lowering these barriers even further. Second, vertical specialization has helped make the linkages between foreign direct investment policy and trade policy stronger than ever. The trade gains from vertical specialization can therefore be realized when countries place greater emphasis on eliminating FDI restrictions.

In the next section, we define vertical specialization more precisely and relate it to other important production concepts, such as outsourcing, vertical foreign direct investment, and vertical integration. We then present our case study and input-output table evidence of the increased importance of vertical specialization. We conclude with a discussion of the possible causes of vertical specialization, as well as its trade policy implications.

\section{VERTICAL SPECIALIZATION}

The story of globalization is a story about specialization. Today, countries focus more and more on producing a relatively narrow range of goods and services. They exchange the fruits of their specialization for other goods and services. The traditional notion of specialization is horizontal-firms or countries become adept at producing particular goods and services from scratch and then export them. We show, however, that an increasingly significant characteristic of world trade is vertical specialization.

Three conditions must hold for our definition of vertical specialization to occur: (1) a good must be produced in multiple sequential stages, (2) two or more countries must specialize in producing some, but not all, stages, and (3) at least one stage must cross an international border more than once. ${ }^{4}$ In other words, vertical specialization occurs when a country uses imported intermediate parts to produce goods it later exports. This definition captures the idea that countries link sequentially to produce a final good.

To obtain a quantitative measure of the amount of trade due to vertical specialization, we define verticalspecialization-based trade to be the value of imported intermediates embodied in a country's exports, multiplied by two. We multiply by two because imported intermediates are counted twice: once as imports and once as embodied in exports. We calculate this trade as:

$$
\begin{aligned}
& \text { (fraction of gross production that is imported } \\
& \text { intermediates }) \times(\text { exports }) \times(2)
\end{aligned}
$$

or, equivalently, as:

\section{(1a) (imported intermediates $) \times($ fraction of gross production that is exported $) \times(2)$.}

From the above formulas, we can see that as the fraction of gross production that is imported intermediates and/or the fraction of gross production that is exported increases, the fraction of trade that is vertical-specialization-based will increase. 
The exhibit below offers a good example. Country 2 imports $\$ 50$ million of parts from Country 1 and, after producing computers, exports $\$ 100$ million of the computers to Country 3. Applying equation 1, we see that vertical-specialization-based trade for Country 2 is ( $\$ 50 /$ $\$ 150) \times \$ 100 \times 2=\$ 200 / 3$ million, which is twice the value of imported intermediates embodied in exports. Because Country 2's total trade is $\$ 150$ million, verticalspecialization-based trade thus accounts for 44 percent of its total trade. However, if one or both of the imported intermediates and exports were zero, vertical-specializationbased trade would also be zero.

Vertical-specialization-based trade is clearly related to trade in intermediate goods, which has also risen sharply in recent decades. However, our definition makes clear that vertical-specialization-based trade can include trade in final goods, as long as some imported intermediates are used to produce those goods. The above example also shows that imports of intermediate goods would not count as vertical-specialization-based trade if the good produced with the imported intermediates was not exported.

Vertical specialization is related to several production concepts including outsourcing, vertical integration, and vertical FDI, all of which have garnered much atten-

An Example of Vertical-Specialization-Based Trade

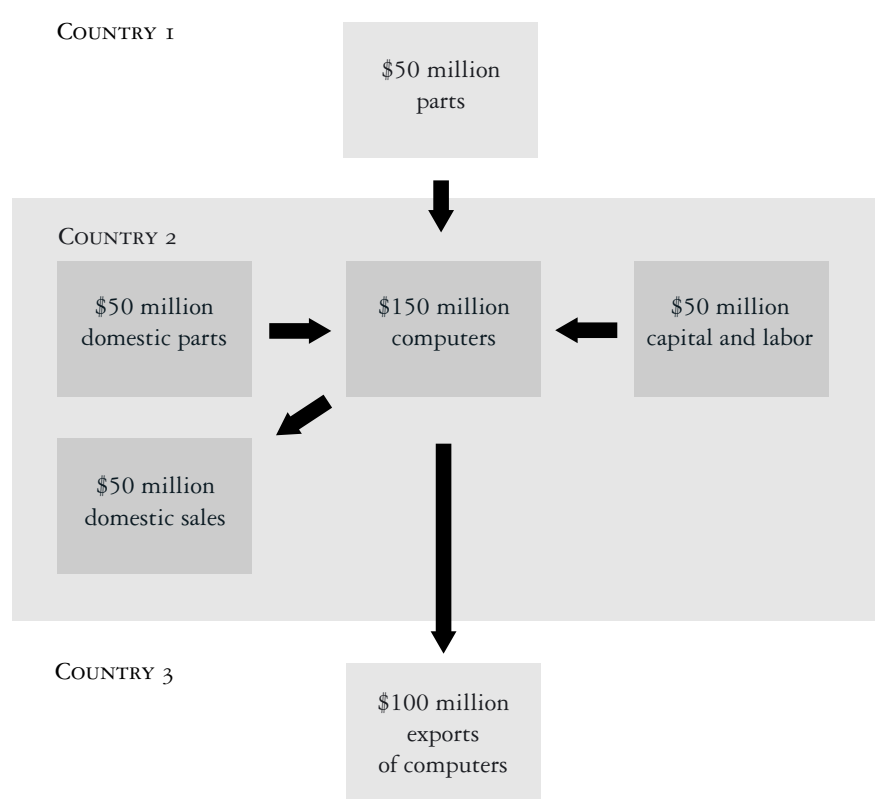

tion in academic research and the popular press. Outsourcing is the relocation of one or more stages of a good that was formerly produced entirely in the home country (see box). Vertical integration and vertical FDI are activities in which multinational firms locate different stages of production of a good or goods in different countries. These concepts are similar to vertical specialization because they are all concerned with the location of production. The main distinction, however, is that vertical specialization concerns the activities of countries, while outsourcing, vertical integration, and vertical FDI involve the behavior of multinational firms. While firm-level production activities represent ways in which country-level vertical specialization can occur, outsourcing and vertical integration and FDI need not imply vertical specialization, and vice versa. ${ }^{5}$ We later show that the industries in which multinational firms are engaged-manufacturing industries, especially

\section{OUTSOURCING AND VeRTICAL SPECIALIZATION}

We define outsourcing as the relocation of one or more stages of the production of a good from the home country. Labor, capital, and/or technology can be transferred in the process. While we regard outsourcing as the act of relocation, others have viewed it more generally as reliance on imported inputs. The examples below illustrate the distinction between vertical specialization and both types of outsourcing:

1. Suppose a firm relocates production of computer components to another country and imports these components from that country. The firm then completes the production of the computers but does not export them. In this case, outsourcing-as we define it-has occurred, but vertical specialization has not. However, if the country does export the final goods, both outsourcing and vertical specialization have occurred.

2. Suppose a country manufactures computers and some of the intermediate inputs are imported. In this case, outsourcing — as others define it - has occurred. If no computers are exported, there is no vertical specialization; if computers are exported, vertical specialization has occurred.

3. According to our definition, outsourcing is not present in the second example. Either way, however, vertical specialization and outsourcing are distinct concepts. 
chemicals, machinery, and equipment - are those in which the share of total trade that is vertical-specialization-based is the largest. 6

\section{EMPIRICAL EVIDENCE: FOUR CASE STUDIES}

To construct empirical measures of vertical-specializationbased trade, ideally we would use data on the production process and direction of trade flow for every stage of each good traded in the world economy. ${ }^{7}$ Unfortunately, these data are impossible to obtain. We can, however, construct detailed estimates of vertical trade on a case-by-case basis. (Appendix A provides additional details on the data sources for our four case studies.)

Implicit in all of our case study calculations is the assumption that countries divide production into two stages-intermediate goods production and final goods production-with one stage occurring in each country. ${ }^{8}$ To the extent that countries divide production into more than two stages, our calculations underestimate the amount of vertical trade. For example, imagine that the United States used pistons imported from Canada to produce engines that are then exported to Canada, where they are assembled into final motor vehicles that are exported back to the United States. In this instance, our calculations would miss one set of trade flows, or one "border crossing."

Our first two case studies illustrate bilateral relationships-that is, relationships in which one country exports goods to a second country, which uses them as inputs to produce goods that are exported back to the first country. In the other two studies, the second country, rather than exporting the goods back to the first country, exports them to a third country.

\section{The 1965 United States-CANAda Auto}

\section{AGREEMENT}

Before the 1965 United States-Canada Auto Agreement, auto trade between the two countries was virtually nonexistent. Tariffs were significant: 17.5 percent on Canadian automotive imports from the United States and 6.5 to 8.5 percent on U.S. automotive imports from Canada. Canadian auto manufacturers (affiliates of GM, Ford,
Chrysler, and American Motors Corporation) produced exclusively for the Canadian market, and almost all vehicles sold in Canada were also made there. The 1965 agreement reduced the tariffs facing producers to zero. ${ }^{9}$ Viewing the United States and Canada as one integrated market after the agreement, U.S. auto companies immediately consolidated production. In Canada, production was narrowed to just a few models, with the output serving the entire North American market. Just four years after the agreement, auto trade soared (Chart 3). The share of Canadian vehicles exported to

Chart 3

U.S.-Canadian Auto Trade: Before and After the i965 Auto Agreement
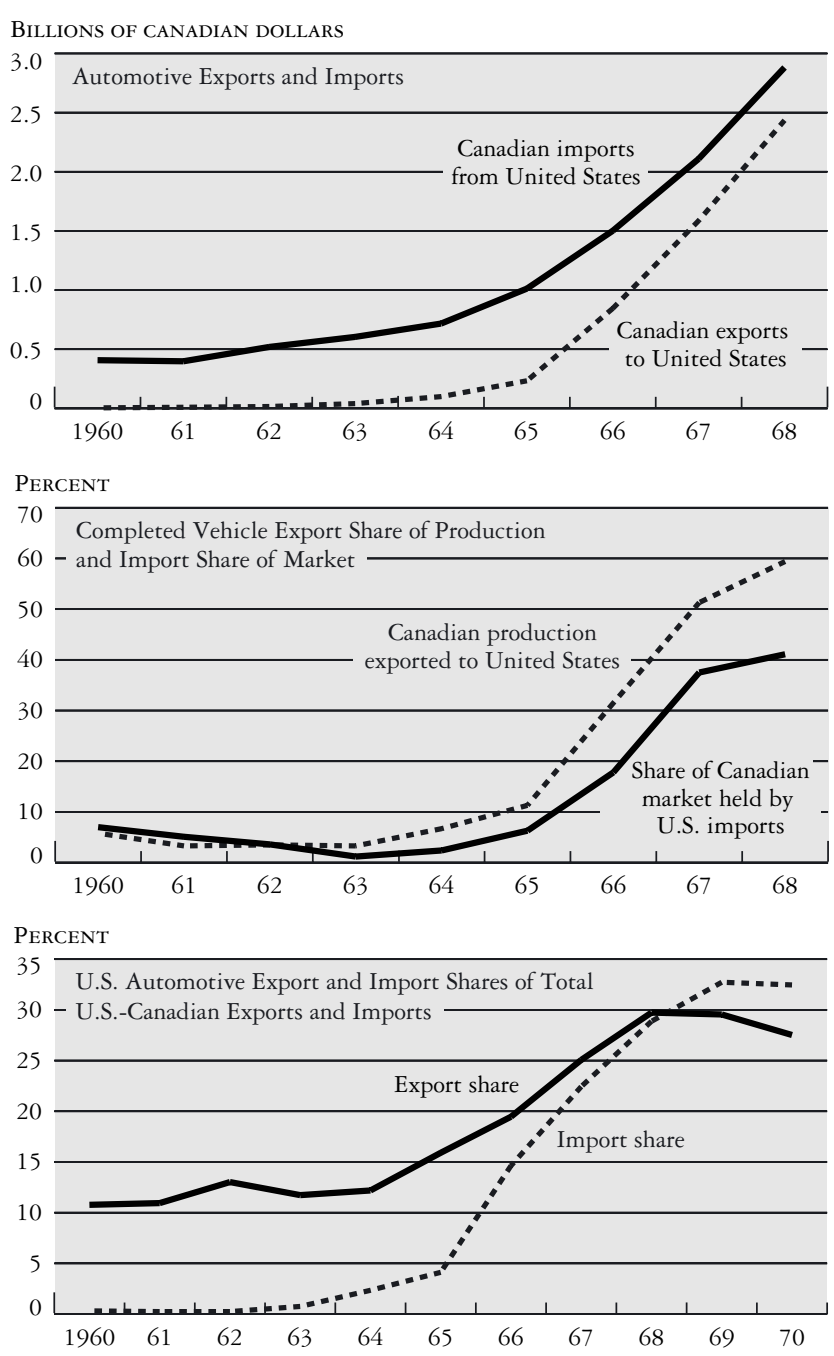

Sources: Top panel: Beigie (1970, p. 71, Table 13); middle panel: Beigie (1970, p. 72, Table 14); bottom panel: U.S. Department of Commerce, Bureau of Economic Analysis, Survey of Current Business, International Monetary Fund, Direction of Trade. 
the United States leaped from 7 percent to 60 percent, and the share of the Canadian automobile market consisting of imported cars jumped from 3 percent to 40 percent (Beigie 1970 , pp. 4-5). The bottom panel of the chart shows that the automobile share of total U.S.-Canadian trade rose immediately, from approximately 8 percent to 30 percent. ${ }^{10}$

These events seem like a textbook example of traditional horizontal specialization, in which there is just more trade in motor vehicles. ${ }^{11}$ Nevertheless, the basic data provide a hint that vertical specialization also occurred. Sixty percent of U.S. auto exports to Canada are engines and parts, while 75 percent of U.S. auto imports from Canada are finished cars and trucks (U.S. Department of Commerce 1994-96). To proceed further, we estimate the level of U.S.-Canadian vertical trade following the auto agreement using data from Ward's Automotive Yearbook, the United Nations Comtrade database, and the U.S. Department of Commerce's Bureau of Economic Analysis (BEA). The United Nations and BEA trade data separate parts trade from vehicles trade, a distinction that is key to our calculation. Our calculation has two steps. First, we attribute trade in auto parts in 1964, before the agreement, entirely to the auto repair market, for which there is no vertical specialization. We also assume that the ratio of repair market trade to total U.S. auto and truck output is constant at its 1964 level in order to calculate estimates of repair trade in future years. We subtract this amount of trade from the overall trade figures to obtain an estimate of parts trade owing specifically to the agreement (Appendix A). Second, we determine the amount of vertical trade generated by the auto agreement, which equals:

$$
\begin{gathered}
2 \times\{[\text { (adjusted }) \text { Canadian parts imports }] \\
\times[\text { fraction of Canadian vebicle production } \\
\text { exported to United States }]+[(\text { adjusted }) \text { U.S. } \\
\text { parts imports }] \times[\text { fraction of U.S. vehicle } \\
\text { production exported to Canada }]\} .
\end{gathered}
$$

Note that we calculate vertical trade in both directions-that is, from the United States to Canada to the United States, and from Canada to the United States to Canada. The fraction of Canadian vehicle production
Chart 4

Vertical Trade as a Percentage of Auto Trade and Auto Trade as a Percentage of Auto Output: The United States and Canada

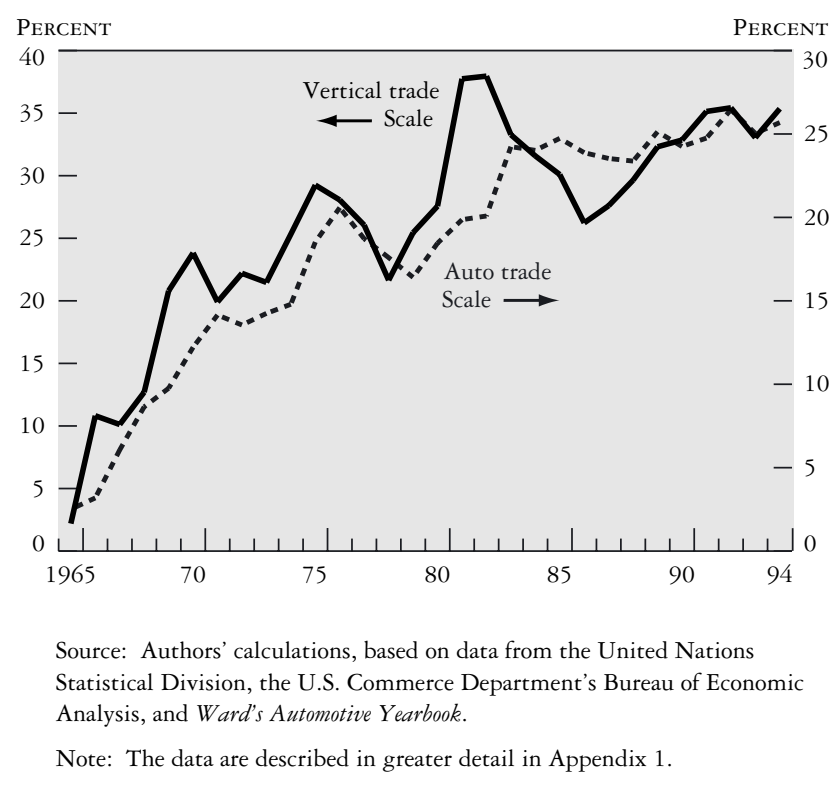

exported to the United States is currently about 80 to 90 percent; by contrast, only a small fraction of U.S. vehicle production is exported to Canada. This means that the vast majority of vertical trade consists of the U.S.-Canadian-U.S. flow. Chart 4 shows the percentage of total automotive trade from 1965 to 1994 that is vertical trade generated by the auto agreement. By 1971, vertical trade had risen from 0 percent to more than 20 percent of total auto trade, and it has continued to trend upward. In recent years, vertical trade has accounted for more than 35 percent of U.S.-Canadian auto trade, or about $\$ 30$ billion. Chart 4 also shows that the share of vertical trade in total U.S.Canadian auto trade is highly correlated with total U.S.Canadian auto trade as a fraction of U.S. auto output; the correlation coefficient is 0.82 .

\section{MEXICO'S MAQUILADORAS}

Mexico's maquiladoras are non-Mexican-owned production plants that complete processing or secondary assembly of imported components for export. ${ }^{12}$ These plants benefit from Mexican laws that exempt from Mexican tariffs parts and materials imported by Mexico for use in maquiladoras. 
Also, U.S. firms that use maquiladoras receive favorable tax treatment from the United States. Under U.S. law, the U.S. components of maquiladora-made goods exported back to the United States are exempt from U.S. tariffs. ${ }^{13}$ Consequently, the only part of the two-way transaction that is dutiable is the Mexican value added in the goods exported back to the United States. The net effect of these policies is that U.S. firms increasingly have turned to vertical specialization by outsourcing to the maquiladoras a large fraction of manufactured goods assembly.

The principal maquiladora industries are electric/ electronics, transportation equipment, and textiles, which together employ more than 73 percent of all maquiladora workers and account for 81 percent of total maquiladora production. The electric/electronics industry is the largest, accounting for almost half of total maquiladora production in 1994. The transportation sector has grown the fastest in recent years, increasing its share of employment from 10 percent in 1982 to 22 percent in 1995.

From the maquiladoras' inception in 1965 until the early 1980s, their growth was steady but not striking. However, propelled by the greater importance given to them by Mexico's de la Madrid administration, maquiladoras grew considerably starting in the mid-1980s. From 1985 to 1997, employment growth in maquiladoras averaged 12.6 percent per year, and almost 900,000 workers were employed in 1997. The maquiladoras' increases in gross production were equally striking, averaging an annual growth rate of 19.7 percent during the same period; gross production was $\$ 44$ billion in $1997 .{ }^{14}$ The growth in production has been accompanied by strong growth in total bilateral trade as a share of Mexico's GDP (Chart 5). Since the late 1980s, U.S. maquiladora imports have represented 45 percent of total U.S. imports, and 60 percent of total non-oil U.S. imports, from Mexico (Hufbauer and Schott 1992, pp. 96-7).

Our maquiladora data include imported intermediates and gross production. In addition, we know that almost all imported intermediates are from the United States and almost all production is exported there; hence, we assume that these shares are 100 percent. ${ }^{15}$ We com- pute vertical-specialization-based trade only for the flow of Mexican imported intermediates from the United States used to produce goods exported back to the United States because we do not have data on U.S. imported intermediates from Mexico that are used to produce goods exported back to Mexico (vertical trade flows in the latter direction are probably not large anyway).

Our calculations indicate that vertical trade has increased significantly. Between 1975 and 1979, the share of total U.S.-Mexican trade attributable to maquiladora vertical trade averaged about 20 percent per year (Chart 5). This share rose to an average of 25 percent in the following decade and of 35 percent in the first half of the 1990s, reaching 39 percent in 1996. Such trade in 1996 represented about $\$ 57$ billion. Because there is surely vertical trade originating from nonmaquiladora channels, we contend that at least half of U.S.-Mexican trade could be due to vertical specialization.

Our analysis also suggests a relationship between the growth in vertical trade and the increase in total bilateral trade as a share of Mexico's GDP (Chart 5). Vertical trade and total bilateral trade have followed similar,

Chart 5

Vertical Trade as a Percentage of Total Trade and Total Trade as a Percentage of GDP:

The United States and Mexico

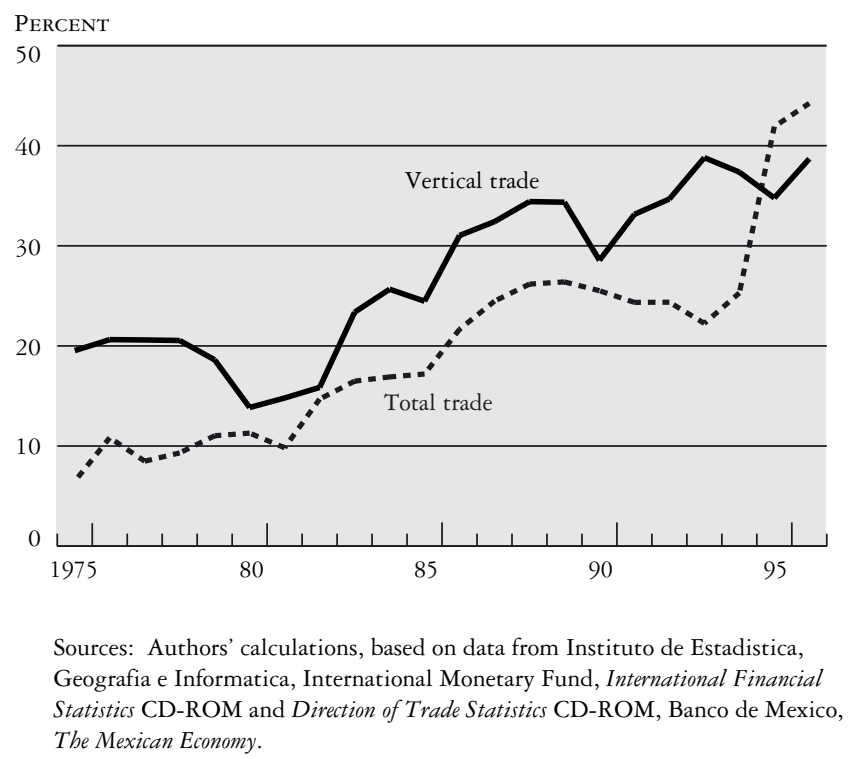


although not identical, paths. The correlation coefficient between the two variables is significantly positive, 0.83 .

\section{JAPAN-ASIA ELECTRONICS TRADE}

To reduce costs, many of Japan's manufacturing industries have been rapidly outsourcing different stages of production, especially final assembly, to Southeast Asia and other countries. In 1996, almost 70 percent of Japanese offshore electronics production facilities were located in just nine developing Asian countries. As of 1995, offshore workers accounted for almost 40 percent of total Japanese electronics industry employees, up from just 25 percent in 1989. It is no surprise, then, that offshore production has surpassed domestic production of both color televisions (in 1988) and VCRs (in 1994).

Using data from the Electronic Industries Association of Japan and the Japan Electronics Bureau, we show patterns of production and exports for the Japanese electronics industry between 1985 and 1995 (Chart 6). We see in the top panel that the export share of components and devices has increased, while the export share of consumer and industrial equipment has remained virtually constant or even decreased during this period. Developing countries in Asia are playing a greater role in the rising importance of components. As of 1995, exports of components to Asia accounted for more than three-fourths of all exports there, more than one-half of all exports of components, and more than one-third of total electronics exports. These components are used primarily for production of other components or final goods such as VCRs and color televisions. Most of this offshore production is then exported back to Japan or to third countries such as the United States.

We make two assumptions to estimate the amount of electronics vertical trade for the countries in which the Japanese electronics industry relocated its production. First, we assume that all electronic components imported from Japan are used as inputs for further production. Second, using Wells' (1993) finding that Japanese electronics subsidiaries in Indonesia export 71 percent of their production, we assume that this percentage applies to all Asian countries with Japanese subsidiaries. Under these assumptions, vertical trade equals

$$
2 \times[\text { imports of components from Japan }] \times[0.71] \text {. }
$$

Applying this formula, we find that in the last ten years vertical-specialization-based trade has almost quadrupled in yen terms and has increased ninefold in dollar terms; as of 1995 , it was approximately $\$ 55$ billion (Chart 6 , bottom panel). By contrast, total electronics exports from Japan during this period increased by only 23 percent in yen terms and by about 81 percent in dollar terms.

Chart 6

\section{JAPANESE ELECTRONICS INDUSTRY}

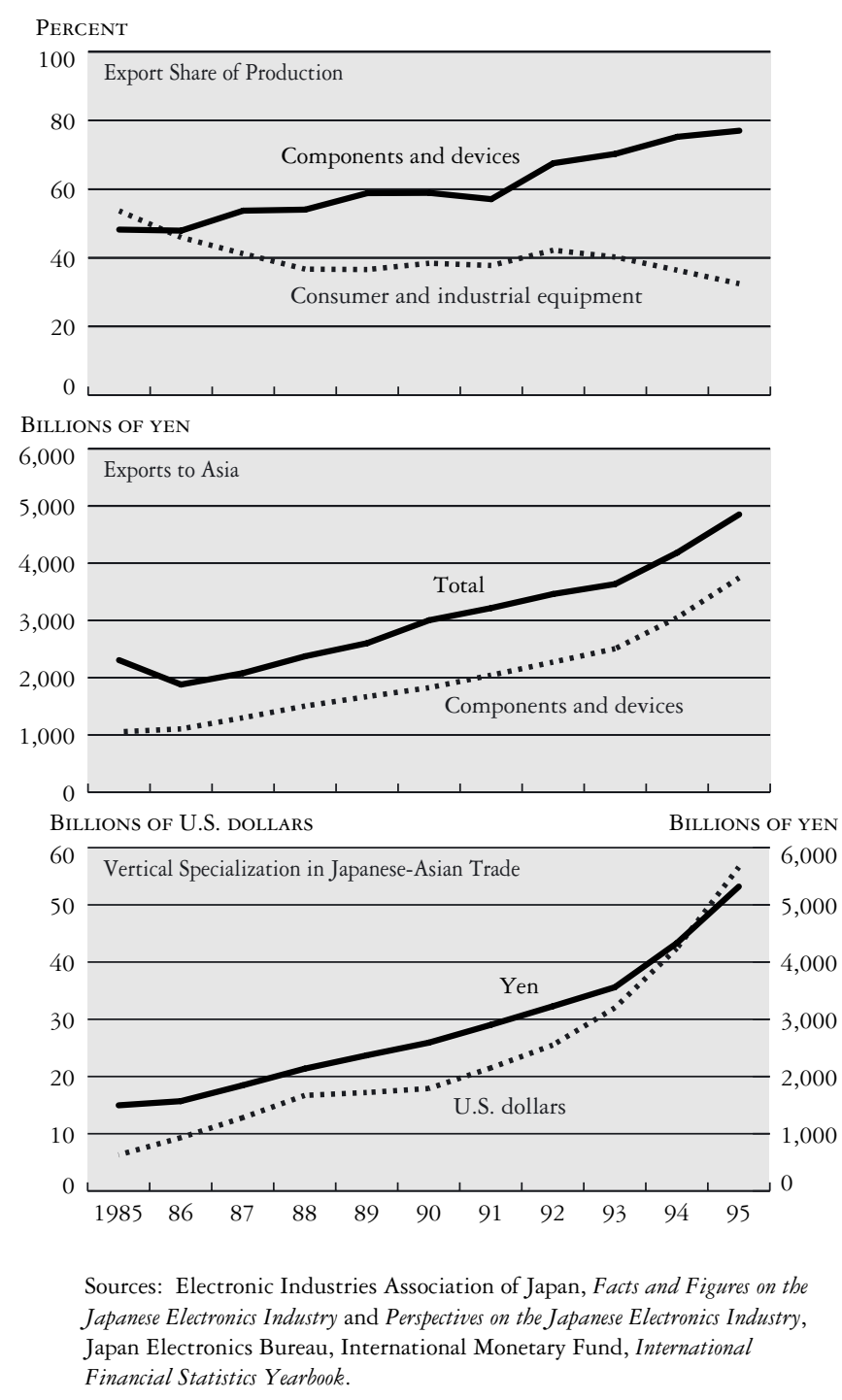




\section{OpEL's SUbSIDIARY IN SPAIN}

Opel, General Motors' affiliate in continental Europe, began operations in Spain in 1982. As of 1994, Opel España made about 22 percent of Spain's total production of 1.8 million passenger cars. From the beginning, Opel España was an important participant in vertical trade, relying heavily on imported inputs to produce automobile parts and final vehicles, most of which were exported. To calculate vertical trade, we use 1983-95 Opel España data on net sales of vehicles and parts, exports of vehicles and parts, and imported parts. As in the two previous case studies, we can calculate this trade only in one direction. (Because countries in the European Union are likely to have extensive production and trade networks, vertical trade in the other direction - that is, Spain exporting intermediate goods to other countries and then importing goods embodying those intermediates - may be significant.) With the data we do have, we estimate the amount of Opel España's vertical-specialization-based trade to be both significant and increasing: $\$ 0.6$ billion in 1983, $\$ 1.8$ billion in 1993, $\$ 2.7$ billion in 1994, and $\$ 3.6$ billion in 1995 .

Using additional data on Spain's auto exports, we can estimate the contribution of vertical trade to the country's overall auto trade. We know that Spain's other auto companies-affiliates of American or European corporations-all export a somewhat smaller fraction of their passenger car production than Opel España, about 70 percent as opposed to 90 percent. Using Opel España's market share of 22 percent, and assuming that these other companies rely on imported inputs to the same degree as Opel, we estimate Spain's total vertical trade in autos to be $\$ 13.5$ billion in 1995, up from \$6.8 billion in 1993 and $\$ 10.1$ billion in 1994 . When we compare these latter figures with total Spanish auto trade of \$21 billion in 1993 and $\$ 25$ billion in 1994, we estimate that at least 40 percent of Spanish auto trade is vertical trade. ${ }^{16}$

\section{EMPIRICAL EVIDENCE: INPUT-OUTPUT TABLES}

We have established the quantitative significance of vertical specialization for our case studies. Next, we ask whether the conclusions reached through case studies of specific operations and products can be extended to entire countries. To resolve this issue, we use input-output tables to calculate vertical-specialization-based trade. Input-output tables characterize, in matrix fashion, the interrelationships among industries in a country's economy. The tables report, for example, how much of the steel industry's output is used as an intermediate input in the motor vehicles industry and vice versa. They also report the gross output and value added of each industry, as well as the amount of each industry's output exported or used domestically for consumption or investment.

Our analysis uses the OECD Input-Output Database, which contains cross-sectional data on ten countries-the G-7 nations, plus Australia, Denmark, and the Netherlands-for selected years between 1968 and 1990. ${ }^{17}$ These ten countries account for about two-thirds of world GDP and more than one-half of world trade. The tables divide the world economy into thirty-five sectors, including twenty-four goods-producing sectors, of which twenty-two are manufacturing. The concentration on manufacturing sectors is important because they increasingly dominate world trade. ${ }^{18}$ For each country, we focus on the goods industries: agriculture and mining, plus the twentytwo manufacturing industries.

The OECD data offer two major advantages. First, they include an "imported transactions" table for each country, which reports the fraction of one sector's inputs imported from another sector. Hence, because the tables provide data on imported inputs, gross production (as well as value added), and exports, we can calculate the amount of vertical trade for each industry, as well as for the country overall. Second, the data provide a consistent set of tables to facilitate comparisons across countries and over time.

The input-output tables do, however, pose an aggregation problem. Each industry produces many goods, but we measure the use of imported inputs and exports at the industry level, rather than for each good. Consider an extreme example of a potential problem: An industry produces just two goods. One good uses imported intermediate inputs but is not exported. The 
other good uses no imported inputs but is exported. In this case, there would be no vertical-specialization-based trade, yet at the industry level we would calculate a positive amount of such trade. However, suppose that the first good relied heavily on imported intermediate inputs and was heavily exported, and the second good used no imported inputs and was not exported. Then, at the

\section{Large countries generally find it easier than}

small ones, for scale economy reasons, to retain

production of every stage of a good. This

rationale explains why the United States,

Germany, and Japan have three of the four

lowest vertical trade shares of total trade.

industry level, we would underestimate the amount of vertical-specialization-based trade. Unfortunately, we do not know whether the former or the latter case is more common, nor do we know the quantitative significance of the "bias."

When we calculate vertical trade as a share of total trade for nine countries in our sample for all available years between 1968 and 1990, two patterns emerge (Chart 7). ${ }^{19}$ First, for every country but Japan, vertical trade as a share of total trade has increased from the first to the last year. Using the most recently available years for each country, we calculate vertical trade in our ten-country sample to be about 14.5 percent of overall trade, up from about 12.0 percent in the earliest years for each country-a 20 percent increase in less than two decades. ${ }^{20}$ Second, there is wide cross-country variation in the amount of vertical trade. Japan, the United States, and Australia, for example, have the least amount of such trade, only about 7 percent of total trade in the final year of our study period. By contrast, 34.7 percent of the Netherlands' total trade was vertical trade in 1986 (the last year for which we have Netherlands data).

Interestingly, our ten-country sample includes the world's largest economies, which are conceivably the least likely to be involved in vertical trade. Large countries generally find it easier than small ones, for scale economy reasons, to retain production of every stage of a good. This rationale explains why the United States, Germany, and Japan have three of the four lowest vertical trade shares of total trade. The rest of the world, which accounts for about half of world trade, may be more like the Netherlandswhich has much higher vertical trade. For example, in calculations not reported here, we find that vertical trade accounted for 28.4 percent of overall trade in Ireland in 1990 and about 23.9 percent in Korea in 1993. Moreover, our case studies suggest that countries like Spain, Malaysia, and the Philippines may also have large vertical trade shares. Consequently, a world vertical trade share on the order of 20 to 25 percent could well be likely.

Within each country, the prominence of vertical trade varies widely across industries (Table 1). Industries with the most vertical trade are motor vehicles, shipbuilding, and aircraft, as well as industrial chemicals, nonferrous metals, and petroleum and coal products; those with the least are agriculture, mining, wood products, and paper products. In Japan, for example, vertical trade accounts for 16 percent of industrial chemicals trade, while it accounts for only 0.1 percent of agriculture trade. There is also wide variation across countries within each sector. For instance, only 4.5 percent of motor vehicles trade in Australia is vertical trade, compared with 49.9 percent in Canada. Canada's figure is similar to the estimate calculated in our case study.

Our analysis also suggests that the increase in vertical trade is linked to the growing trade share of output. The positive relationship over time between vertical trade as a share of total trade and total trade as a share of gross merchandise output is evident in Chart 7. The correlation coefficient between the two variables for every country exceeds 0.79 , except for Japan, where the correlation is $0.26{ }^{21}$ To capture more formally the relationship between the trade share of output and vertical trade, we also perform 
Vertical Trade as a Percentage of Total Trade and Total Trade as a Percentage of Gross Merchandise Output in Selected Countries
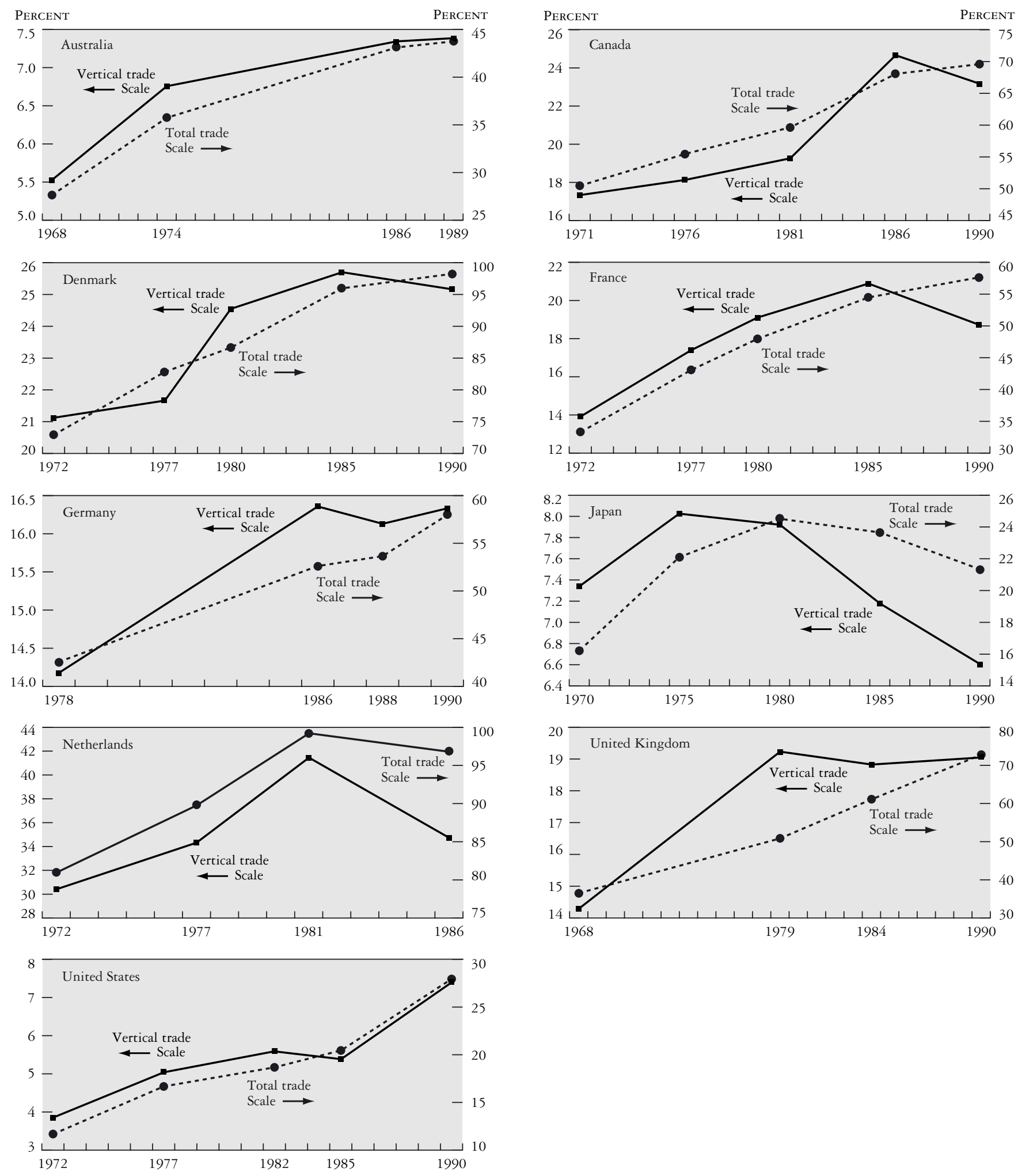

Source: Authors' calculations, based on the OECD's Input-Output Database.

Note: Italy is not shown because data were available only for 1985. 
an ordinary least squares regression of total trade as a share of gross merchandise output on vertical trade as a share of total trade for all countries. We include in our regressions country-specific dummy variables to capture differences due to such factors as country size, GDP per capita, and distance from other countries. The regression results are reported below with the standard errors of the coefficient estimates in parentheses (we do not report the coefficients on the country-specific dummy variables):

$\begin{array}{cl}\text { (4) Total trade }= & 0.03+2.92 \times \text { vertical trade (share } \\ \text { (share of gross } & \text { of total trade) } \\ \text { merchandise output }) & (0.03)(0.41) \\ & \text { adjusted } \mathrm{R}^{2}=0.95 .\end{array}$

We find that the coefficient on vertical trade is statistically significant at the 1 percent level. The coefficient estimate implies that an increase of 1 percentage point in vertical trade as a share of total trade is associated with an increase of 2.92 percentage points in total trade as a share of gross merchandise output, an economically significant amount. $^{22}$

We also employ growth decompositions to assess which industries account for the increase in a country's vertical trade as a share of total trade. The overall growth in vertical trade as a share of total trade depends on two forces: the change in each industry's vertical trade as a share of industry trade and the change in each industry's share of total trade. (Appendix B gives an algebraic derivation of the growth decomposition formula.) We examine the contribution of different industries to the growth in vertical trade as a share of total trade for Canada, France, Japan, the United Kingdom, and the United States. We concentrate

\begin{tabular}{|c|c|c|c|c|c|c|c|c|c|c|}
\hline Industry & $\begin{array}{c}\text { Australia } \\
1989\end{array}$ & $\begin{array}{c}\text { Canada } \\
1990\end{array}$ & $\begin{array}{c}\text { Denmark } \\
1990\end{array}$ & $\begin{array}{c}\text { France } \\
1990\end{array}$ & $\begin{array}{c}\text { Germany } \\
1990\end{array}$ & $\begin{array}{l}\text { Italy } \\
1985\end{array}$ & $\begin{array}{c}\text { Japan } \\
1990\end{array}$ & $\begin{array}{l}\text { Netherlands } \\
1986\end{array}$ & $\begin{array}{c}\text { United } \\
\text { Kingdom } \\
1990\end{array}$ & $\begin{array}{c}\text { United } \\
\text { States } \\
1990\end{array}$ \\
\hline \multicolumn{11}{|l|}{ CHEMICALS } \\
\hline Industrial chemicals & 5.4 & 14.4 & 27.6 & 24.5 & 22.7 & 20.8 & 15.7 & 49.3 & 24.8 & 9.3 \\
\hline Drugs and medicines & 3.8 & 3.4 & 31.0 & 25.7 & 0.0 & 16.4 & 1.9 & 32.2 & 15.2 & 3.5 \\
\hline \multicolumn{11}{|l|}{ MACHINERY } \\
\hline Nonelectrical machinery & 2.6 & 12.2 & 27.4 & 16.7 & 15.6 & 25.2 & 6.6 & 25.1 & 20.3 & 6.7 \\
\hline Office and computing machinery & 0.0 & 29.2 & 0.0 & 19.8 & 11.5 & 28.2 & 8.7 & 24.1 & 29.3 & 16.7 \\
\hline $\begin{array}{l}\text { Electrical apparatus, not elsewhere } \\
\text { categorized }\end{array}$ & 3.6 & 9.5 & 23.1 & 18.6 & 13.6 & 24.5 & 12.0 & 41.2 & 19.3 & 7.2 \\
\hline $\begin{array}{l}\text { Radio, TV, and communication } \\
\text { equipment }\end{array}$ & 3.3 & 29.2 & 29.9 & 12.6 & 0.0 & 17.8 & 9.1 & 0.0 & 20.8 & 7.6 \\
\hline Shipbuilding and repairing & 8.3 & 15.4 & 41.8 & 29.6 & 26.4 & 29.0 & 7.3 & 38.6 & 18.6 & 8.4 \\
\hline Other transport & 5.2 & 26.1 & 22.0 & 10.5 & 0.0 & 15.4 & 7.2 & 15.4 & 16.6 & 8.1 \\
\hline Motor vehicles & 4.5 & 49.9 & 0.0 & 21.1 & 22.4 & 16.1 & 5.6 & 25.4 & 20.0 & 8.7 \\
\hline Aircraft & 2.4 & 28.6 & 0.0 & 38.4 & 16.7 & 24.2 & 7.3 & 52.5 & 34.5 & 11.6 \\
\hline Professional goods & 4.2 & 11.8 & 27.6 & 11.3 & 11.6 & 13.1 & 7.4 & 24.9 & 16.8 & 5.8 \\
\hline \multicolumn{11}{|l|}{ OTHER } \\
\hline Agriculture, forestry, and fishing & 9.4 & 8.8 & 20.4 & 10.9 & 3.7 & 4.3 & 0.1 & 13.0 & 6.1 & 4.8 \\
\hline Mining and quarrying & 12.6 & 5.8 & 3.5 & 3.5 & 1.3 & 0.0 & 0.0 & 4.8 & 10.5 & 0.8 \\
\hline Food, beverages, and tobacco & 7.4 & 7.9 & 25.9 & 12.4 & 15.1 & 10.2 & 0.9 & 36.8 & 10.1 & 4.6 \\
\hline Textiles, apparel, and leather & 9.2 & 7.6 & 29.4 & 18.1 & 15.1 & 29.6 & 5.2 & 34.6 & 19.1 & 2.8 \\
\hline Wood products and furniture & 5.8 & 12.9 & 32.8 & 9.5 & 11.4 & 18.6 & 1.3 & 14.3 & 5.9 & 3.9 \\
\hline Paper, paper products, and printing & 3.0 & 12.2 & 16.2 & 12.2 & 18.6 & 13.9 & 4.2 & 21.0 & 12.2 & 7.2 \\
\hline Petroleum and coal products & 11.4 & 34.7 & 15.3 & 25.6 & 13.4 & 46.1 & 11.1 & 98.7 & 12.5 & 15.5 \\
\hline Rubber and plastic products & 2.6 & 14.4 & 32.6 & 29.3 & 19.2 & 32.3 & 8.6 & 32.1 & 19.9 & 5.7 \\
\hline Nonmetallic mineral products & 1.4 & 5.9 & 20.0 & 8.1 & 9.9 & 20.8 & 6.6 & 13.9 & 11.3 & 3.0 \\
\hline Iron and steel & 9.3 & 15.5 & 16.9 & 21.5 & 11.8 & 31.9 & 13.4 & 27.1 & 20.9 & 4.7 \\
\hline Nonferrous metals & 14.2 & 28.7 & 19.5 & 36.0 & 27.0 & 13.2 & 10.3 & 0.0 & 24.7 & 12.2 \\
\hline Metal products & 9.3 & 11.9 & 26.3 & 13.5 & 16.1 & 22.7 & 7.3 & 27.7 & 17.2 & 8.9 \\
\hline Other manufacturing & 5.4 & 10.4 & 28.6 & 10.8 & 16.6 & 42.1 & 4.2 & 21.3 & 11.0 & 2.8 \\
\hline TOTAL GOODS & 7.4 & 23.2 & 25.2 & 18.7 & 16.3 & 19.6 & 6.6 & 34.7 & 19.1 & 7.4 \\
\hline
\end{tabular}

Source: Authors' calculations, based on the OECD's Input-Output Database. 
on the chemical and machinery sectors because they have accounted for the majority of manufacturing export share increases from the 1970s to the 1980s (see Ishii and Yi [1997, Table A.6]).

The top half of Table 2 presents our growth decomposition results. (The bottom half reports the change in each industry's vertical trade share of total industry trade, for reference.) In every country except Japan, we find that machinery accounted for at least 65 percent of the increase in the overall share of trade that is vertical trade between the first and last year of our data sample. Chemicals accounted for a smaller fraction of this increase across the five countries. Overall, in every country except Japan, these two industries together accounted for more than 75 percent of the growth in vertical trade as a share of total trade. Even in Japan, these industries' vertical trade as a share of total industry trade increased. ${ }^{23}$ These results support our contention that, by and large, the industries that account for overall export growth are the same ones that account for vertical trade growth.

\begin{tabular}{|c|c|c|c|c|}
\hline \multicolumn{5}{|c|}{$\begin{array}{l}\text { Table } 2 \\
\text { INDUSTRY CONTRIBUTION TO GROWTH IN VERTICAL } \\
\text { SPECIALIZATION FROM FIRST TO LAST YEAR OF SAMPLE: } \\
\text { SELECTED COUNTRIES } \\
\text { Percent }\end{array}$} \\
\hline Country & Chemicals & Machinery & Other & Total \\
\hline Canada & 6.7 & 72.0 & 21.4 & $100^{\mathrm{a}}$ \\
\hline France & 23.7 & 65.0 & 11.3 & 100 \\
\hline Germany & 4.8 & 80.1 & 15.1 & 100 \\
\hline Japan & -40.9 & -263.9 & 404.9 & $100^{\mathrm{a}}$ \\
\hline United Kingdom & 12.7 & 124.5 & -37.1 & $100^{\mathrm{a}}$ \\
\hline United States & 8.7 & 68.6 & 22.7 & 100 \\
\hline \multicolumn{5}{|c|}{ Change in Vertical Trade as a Share of Total Industry Trade ${ }^{b}$} \\
\hline Canada & 127.9 & 34.9 & 25.0 & 33.7 \\
\hline France & 65.3 & 63.9 & 7.4 & 34.5 \\
\hline Germany & 3.9 & 30.6 & 5.5 & 15.2 \\
\hline Japan & 50.2 & 106.1 & -61.5 & -10.1 \\
\hline United Kingdom & 29.1 & 151.2 & -21.5 & 33.5 \\
\hline United States & 117.2 & 134.2 & 45.4 & 92.2 \\
\hline
\end{tabular}

Source: Authors' calculations, based on the OECD's Input-Output Database.

Notes: A detailed explanation of these growth decompositions is found in Appendix B. The industries that make up the categories "chemicals," "machinery," and "other" are listed in Table 1.

${ }^{\text {a }}$ Row does not sum to 100 because of rounding.

${ }^{b}$ Totals are weighted averages of the figures in columns 1-3, where the weights are each industry's share of total trade.
We use growth decompositions to answer another question: How has the growth of vertical trade contributed to the growth of total exports? Our decompositions allow us to calculate the contribution of vertical trade relative to horizontal-specialization-based trade. This calculation shows the percentage of growth attributable to each type of specialization. (Appendix B provides more details on the
By and large, the industries that account for
overall export growth are the same ones that
account for vertical trade growth.

decomposition.) We find that for Canada and the Netherlands, almost 50 percent of the growth of exports from the first to the last year in the sample is due to growth in vertical trade (Table 3). In Denmark, France, and the United Kingdom, growth in vertical trade accounts for more than 25 percent of export growth. Only in the United States, Australia, and Japan does growth in vertical trade account for a small fraction of export growth. Table 3 also presents the change in vertical trade as a share of gross merchandise output for each country. We see that because vertical trade is still a relatively small fraction of total trade, growth in vertical trade accounts for less overall export growth than does growth in horizontal trade. However, vertical trade's increasing importance explains why its contribution to total export growth exceeds its share of total trade in all countries except Japan.

\section{CAUSES AND POLICY IMPLICATIONS of VERTICAL SPECIALIZATION}

We have shown that vertical-specialization-based trade is rapidly increasing as a share of total trade. While our analysis does not permit us to conclude that the growth in vertical trade is causing the growth in world trade, three of our findings indicate a tight link between the two patterns. First, vertical trade as a share of total trade and trade as a 
CONTRIBUTIONS OF VERTICAL TRADE AND HORIZONTAL TRADE TO CHANGE IN EXPORT SHARE OF GROSS OUTPUT

FROM FIRST TO LAST YEAR OF SAMPLE: SELECTED COUNTRIES

\begin{tabular}{|c|c|c|c|c|c|c|c|}
\hline \multirow{3}{*}{$\begin{array}{l}\text { Country } \\
\text { Australia }\end{array}$} & \multicolumn{4}{|c|}{$\begin{array}{l}\text { Vertical Trade as a Percentage of Gross Output } \\
\text { (Exports Only) }^{\mathrm{a}}\end{array}$} & \multirow{2}{*}{$\begin{array}{l}\text { Change in Export } \\
\text { Share of Gross Output }\end{array}$} & \multicolumn{2}{|c|}{ Percentage of Change Due to Increase in } \\
\hline & \multicolumn{2}{|c|}{ First Year } & \multicolumn{2}{|c|}{ Last Year } & & Vertical Trade & Horizontal Trade \\
\hline & 1968 & 0.8 & 1989 & 1.6 & 0.06 & 13.4 & 86.6 \\
\hline Canada & 1971 & 4.4 & 1990 & 8.1 & 0.08 & 43.7 & 56.3 \\
\hline Denmark & 1972 & 7.7 & 1990 & 12.4 & 0.17 & 27.3 & 72.7 \\
\hline France & 1972 & 2.3 & 1990 & 5.4 & 0.11 & 28.4 & 71.6 \\
\hline Germany & 1978 & 3.0 & 1990 & 4.7 & 0.09 & 19.4 & 80.6 \\
\hline Japan & 1970 & 0.6 & 1990 & 0.7 & 0.03 & 3.2 & 96.8 \\
\hline Netherlands & 1972 & 12.3 & 1986 & 16.8 & 0.10 & 47.4 & 52.6 \\
\hline United Kingdom & 1968 & 2.6 & 1990 & 6.9 & 0.15 & 29.6 & 70.4 \\
\hline United States & 1972 & 0.2 & 1990 & 1.0 & 0.07 & 11.9 & 88.1 \\
\hline
\end{tabular}

Source: Authors' calculations, based on the OECD's Input-Output Database.

Note: A detailed explanation of these growth decompositions is found in Appendix B.

${ }^{a}$ Because we are accounting for the export share of gross output, we divide vertical trade by 2 to obtain the amount of vertical-specialization-based exports.

share of gross merchandise output are highly correlated over time in our sample of OECD countries. Second, the industries that account for the increase in total exports as a share of GDP — chemicals and machinery-also account for the increase in vertical trade as a share of total trade. Third, for most of our sample countries, growth in vertical trade accounts for 25 percent or more of the growth in overall trade. These findings link the increased internationalization of production to the rising trade shares of GDP and, consequently, enhance our understanding of the globalization of goods and services flows.

These findings raise two key questions: What have been the causes of vertical-specialization-based trade? And what are its consequences, especially the trade policy implications? Although these questions merit a more rigorous examination than we afford them here, we can shed some light on them.

\section{Causes of Vertical Specialization}

Most economists agree that decreases in tariff and nontariff trade barriers, as well as improvements in communications and the transportation of goods, have led to increased world trade. These decreased trade barriers and improvements in "distance-reducing" technologies have enabled countries to specialize in goods that they can produce relatively more efficiently. ${ }^{24}$ China, for example, has become relatively more adept at manufacturing consumer products, while the United States has focused more on manufacturing hightech products such as airplanes and business computers.

This concept of specialization, however, is the traditional horizontal one, which emphasizes production and trade of goods made entirely in one country. Vertical specialization carries the notion of specialization further, describing a process in which countries acquire expertise in particular stages of production. For example, computer production requires a skill-intensive stage — designing and manufacturing the chips-and a labor-intensive stageassembling the computer. Vertical specialization allows countries to unbundle these stages so they can focus on those activities in which they are relatively more efficient. The reductions in trade barriers and improvements in transportation and communications technologies have facilitated this multicountry production sequence and thus have led to increased vertical specialization.

This phenomenon leaves open the question, Why has vertical specialization grown more rapidly than horizontal specialization? One answer is that improvements in communications technologies may favor vertical trade. Advances in such media as faxes, phones, pagers, e-mail, and videoconferencing have made it easier for countries to coordinate and monitor production in diverse locations. The dramatic increases in trans-Atlantic cable capacity and 
the corresponding reductions in the cost of trans-Atlantic communications have also encouraged frequent interaction between firms in different countries. ${ }^{25}$ Since the sequential production nature of vertical specialization requires intensive oversight and coordination of production, these technological advances would tend to benefit verticalspecialization-based trade more than horizontalspecialization-based trade. ${ }^{26}$

Our case studies point to another explanation for vertical specialization's rising importance. When a good crosses only one border, tariffs and transportation costs are incurred only once. When a good crosses multiple borders, as in vertical-specialization-based trade, even low tariff rates of 2 to 4 percent are magnified as they are repeatedly applied to the good-in-process. This multiple taxation results effectively in much higher rates of protection. Therefore, reductions in these tariff rates will spur vertical specialization more than they will horizontal specialization. For example, the tariff rates on automotive trade between the United States and Canada before the 1965 Auto Agreement were roughly 10 to 15 percent, which was not high by historical standards. Yet the elimination of these tariffs resulted in a sixfold increase in auto trade in just four years, and raised the share of total trade accounted for by vertical specialization from zero to 20 percent in six years. Our maquiladora case study also suggests that tariff reductions have had a proportionately greater effect on vertical trade than on horizontal trade. Tariffs were reduced on both sides of the border; in particular, U.S. tariffs were changed so that they were levied only on Mexico's value added. This action removed the multiple-border-crossing penalty and led to more vertical-specialization-based trade.

\section{POLICY IMPLICATIONS}

One clear policy implication of vertical specialization is that further tariff liberalization could yield substantial gains. This is true even though tariff rates in the developed countries are already quite low, approximately 5 percent or less. Moreover, the gains would become greater as vertical specialization increased. $^{27}$

A second implication is that the linkage between trade policy and foreign direct investment policy is likely to tighten. Recall that all of our case studies involve multinational firms engaging in vertically integrated foreign direct investment. Absent firms' ability to invest freely in foreign countries, vertical-specialization-based trade may not occur. Similarly, it might not make sense to open a country to increased FDI inflows without also liberalizing import and export barriers. The notion that trade liberalization and investment liberalization are complementary has recently been supported by the theoretical literature as well (see, for example, Markusen [1997]).

One other trade policy issue is worthy of further consideration. Recently, there has been controversy surrounding the value of regional trade agreements such as the

\section{One clear policy implication of vertical specialization is that further tariff liberalization could yield substantial gains.}

North American Free Trade Agreement, as opposed to broader agreements under the auspices of the World Trade Organization (see, for example, Bergsten [1997] and Bhagwati [1997]). The main argument against regional trade agreements is that they often create barriers between participating and nonparticipating countries; hence, trade "diversion" could occur, in which participating countries specialize in producing goods that nonparticipating countries would produce in a completely free world market. In other words, the gains to participating countries may be exceeded by the losses to nonparticipating countries.

It would be interesting to know how the increased importance of vertical specialization would affect gain-andloss calculations. For example, would regional trade agreements lead to more or less trade diversion? What would happen to the attractiveness of regional trade agreements relative to world trade agreements? We note that all of our case studies involve either regional trading agreements or arrangements. In each case study, a relatively low-wage country engages in final assembly and a relatively high- 
wage country engages in parts and components production.

These regional agreements and arrangements clearly boost trade and produce gains for the participants. Whether these gains come at the expense of other countries is yet to be determined.

\section{CONCLUSION}

The rising international trade shares of GDP are probably the most commonly cited evidence of the globalizing world economy. In this article, we identify a deeper dimension of the rising trade shares: the increased importance of imported inputs in the production of goods that are exported-that is, vertical specialization. Our evidence from case studies and input-output tables points to large and increasing shares of trade that can be attributed to ver- tical-specialization-based trade. In some of the smaller countries examined, the shares of total trade represented by vertical trade approach 50 percent.

Hence, globalization has gone beyond just "more trade." The nature of trade has changed to the point where countries increasingly specialize in producing particular stages of a good, rather than making a complete good from start to finish. This vertical trade is also what links heightened international trade to greater international production. In all likelihood, the forces that have led to increased vertical trade-lower trade barriers and improvements in transportation and communications technologies-will continue. Thus, we can expect the importance of vertical trade to grow as the world economy heads into the twentyfirst century. 


\section{Appendix A: Calculations and Data Sources for Case Studies of Vertical Specialization}

\section{United States-Canada Auto Trade}

Before the auto agreement, most automotive trade consisted of engines and parts. We conservatively attribute this trade entirely to the repair market. Because this trade is not vertical-specialization-based, in the first step of our calculation we estimate trade in the repair market from 1965 to the present and subtract that amount from the raw trade figures. We calculate the ratio of U.S. parts imported from Canada (and the ratio of Canadian parts imported from the United States) to total U.S. auto and truck output in 1964, and then assume that the ratios stay constant over time. Parts trade in the repair market in future years can then be estimated by multiplying these ratios by U.S. auto and truck output in those years. We subtract these estimates from the actual parts trade figures; the difference is our estimate of the parts trade destined for auto assembly that can be attributed to the auto agreement.

Our trade data are obtained from the United Nations Statistical Division's Comtrade Database, except for parts trade data between 1982 and 1994. Here, we use BEA figures because they include parts that are shipped for use in autos, such as air conditioners, but are counted by the United Nations in another, non-auto parts, category.
The discrepancy between the United Nations and the BEA figures becomes significant only in the 1980s. Our "fraction of production exported" figures are obtained from Ward's Automotive Yearbook (1969-96).

\section{United States-MeXico MaQuiladora Trade}

Our trade data come from the International Monetary Fund's Direction of Trade Statistics CD-ROM and from Banco de Mexico; the maquiladora data come from Instituto Nacional de Estadistica, Geografia e Informatica (INEGI).

\section{JAPAN-ASIA ELECTRONICS TRADE}

Our data are obtained from the Electronic Industries Association of Japan and the Japan Electronics Bureau.

\section{OPEL ESPAÑA TRADE}

Our value data on Opel España are obtained from the secretary-general of Opel España. Data on the number of cars produced and exported by all companies in Spain are obtained from the American Automobile Manufacturer's Association. Total Spanish auto trade data are obtained from the United Nations Statistical Division's International Trade Statistics Yearbook (1994). 


\section{APPENDIX B: GROWTH DECOMPOSITIONS}

1. Industry contribution to growth in vertical trade as a share of total trade (Table 2):

Assume for simplicity that there are just two industries, $\mathrm{C}$ and $\mathrm{M}$.

$\mathrm{VSBT}_{\mathrm{i}}=$ vertical-specialization-based trade in industry i. $\mathrm{i}=\mathrm{C}, \mathrm{M}$

$\mathrm{HSBT}_{\mathrm{i}}=$ horizontal-specialization-based trade in industry i. $\mathrm{i}=\mathrm{C}, \mathrm{M}$

$\mathrm{TT}_{\mathrm{i}}=\mathrm{VSBT}_{\mathrm{i}}+\mathrm{HSBT}_{\mathrm{i}}=$ total trade in industry i. $\mathrm{i}=\mathrm{C}, \mathrm{M}$

$\mathrm{TT}=\mathrm{TT}_{\mathrm{C}}+\mathrm{TT}_{\mathrm{M}}=$ total trade in the country

$\mathrm{VSBT}=\mathrm{VSBT}_{\mathrm{C}}+\mathrm{VSBT}_{\mathrm{M}}=$ total VSBT in the country

$\Delta \mathrm{Z}=$ growth in $\mathrm{Z}$ from initial year to final year

$$
\begin{aligned}
& \frac{\mathrm{VSBT}}{\mathrm{TT}}= \frac{\mathrm{VSBT}_{\mathrm{C}}}{\mathrm{TT}_{\mathrm{C}}} \times \frac{\mathrm{TT}_{\mathrm{C}}}{\mathrm{TT}}+\frac{\mathrm{VSBT}_{\mathrm{M}}}{\mathrm{TT}_{\mathrm{M}}} \times \frac{\mathrm{TT}_{\mathrm{M}}}{\mathrm{TT}} \\
& \quad \text { (industry contribution to VSBT as share of total trade) }
\end{aligned}
$$

(industry contribution to growth in VSBT as share of total trade)

(industry C's contribution is the first term on the right-hand-side of the equation divided by the left-hand-side of the equation)

2. Contribution of vertical trade and horizontal trade to change in export share of gross output (Table 3):

VSBT $=$ vertical-specialization-based trade

HSBT = horizontal-specialization-based trade

$\mathrm{X}=$ total merchandise exports

$\mathrm{Y}=$ overall gross merchandise output

$\Delta \mathrm{Z}=$ growth in $\mathrm{Z}$ from initial year to final year

Overall export share of gross output $=\mathrm{X} / \mathrm{Y}$

Vertical specialization export share of gross output $=(\mathrm{VSBT} / 2) / \mathrm{Y}$

We divide VSBT by 2 because we are looking only at exports, not total trade.

Horizontal specialization export share of gross output $=\mathrm{HSBT} / \mathrm{Y}=(\mathrm{X}-\mathrm{VSBT} / 2) / \mathrm{Y}$

$\mathrm{X} / \mathrm{Y}=(\mathrm{VSBT} / 2) / \mathrm{Y}+\mathrm{HSBT} / \mathrm{Y}$

$\Delta(\mathrm{X} / \mathrm{Y})=\Delta((\mathrm{VSBT} / 2) / \mathrm{Y})+\Delta(\mathrm{HSBT} / \mathrm{Y})$

Contribution of vertical specialization $=\Delta((\mathrm{VSBT} / 2) / \mathrm{Y}) / \Delta(\mathrm{X} / \mathrm{Y})$ 


\section{ENDNOTES}

The authors thank Lucinda Vargas-Ambacher and Tomoko Mischke for providing data and information on the maquiladoras and the Japanese electronics industry, respectively, and Jim Harrigan and two anonymous referees for very belpful comments.

1. Many economists, including Krugman (1995) and Irwin (1996), have noted that the international trade shares today are not much higher than they were in the early twentieth century. Nevertheless, the growth in trade is striking, and these economists acknowledge that the nature of trade is different today.

2. Balassa (1967, p. 97) may have coined the term vertical specialization. We later show how our adapted definition differs from his.

3. These case studies draw from Ishii and Yi (1997).

4. Balassa's definition of vertical specialization encompasses parts 1 and 2 of our definition. We also choose to include a part 3 to distinguish vertical specialization from intermediate goods trade in a broad sense. Sanyal and Jones (1982), among others, note that most imported goods-even so-called final goods such as motor vehicles-need sales and marketing services "added on" to them. Thus, almost all imported goods can be viewed as intermediate goods. By examining those goods that involve more than one border crossing, we limit our study to goods destined for export that are actually created through the sequential contributions of different countries. We thereby avoid the more ambiguous notion of intermediate goods.

5. Take Nike as an example. By most definitions, Nike is not a vertically integrated multinational firm because the footwear production occurs through arm's-length relationships. Yet to the extent that the footwear-producing countries import Nike services and other inputs and export Nike footwear, vertical-specialization-based trade occurs. In addition, vertical integration and vertical FDI deal with issues of ownership and internalization; vertical specialization does not.

6. In 1989, chemicals and allied products, machinery, and transportation equipment accounted for about 60 percent of manufacturing multinational gross product and about 35 percent of total multinational gross product (see Mataloni and Goldberg [1994]).

While multinational firms account for a majority of U.S. trade, their share of U.S. trade declined from 1977 to the mid-1990s. Zeile (1993, 1995 ) shows that the importance of foreign multinational firms to U.S. trade has been increasing; nevertheless, overall U.S. and foreign multinational trade has still been declining. These facts indicate that vertical trade goes beyond multinational firms.

7. Hereafter, "vertical-specialization-based trade" and "vertical trade" are used interchangeably.
8. While each good likely requires numerous production steps, we assume that these steps can be grouped into two stages.

9. See Economic Council of Canada (1975, p. 197). The agreement included two important restrictions: total production in Canada roughly had to match total sales in Canada, and 60 percent of the value added in Canadian-made cars had to be of Canadian origin (Wonnacott and Wonnacott 1967). A plausible argument can be made that the absence of these restrictions would have led to more vertical-specialization-based trade.

10. U.S. vehicles, engines, and parts exported to Canada as a fraction of total exports to Canada increased from 13 percent in 1964 to 30 percent in 1968. U.S. vehicles, engines, and parts imported from Canada as a fraction of total imports from Canada increased from less than 3 percent in 1964 to about 30 percent in 1968. As of 1995, engines and parts accounted for about 40 percent of U.S.-Canadian automotive trade. Total U.S. trade in vehicles, engines, and parts relative to U.S. auto and truck output increased from 9 percent in 1960 to 61 percent in 1994. Engines and parts accounted for more than 45 percent of total automotive trade in 1994 .

11. Indeed, one of the major undergraduate textbooks in international economics, Krugman and Obstfeld (1997), discusses the auto agreement as such.

12. U.S. firms own the vast majority of maquiladoras, although there is increasing ownership by firms from Japan, Korea, and some European nations.

13. These are Harmonized Tariff System (HTS) items 9802.00 .60 and 9802.00.80. They were formerly known as items 806.30 and 807.00 of the Tariff Schedule of the United States (TSUS). Item 9802.00.60 concerns tariff treatment for metal of U.S. origin processed in a foreign location and returned to the United States, while item 9802.00.80 involves goods that contain U.S.-made components (Hufbauer and Schott 1992, p. 93).

14. Much of the data that follow originate from Instituto Nacional de Estadistica, Geografia e Informatica (INEGI). Hanson (1996) draws from these data as well.

15. Over the last decade, two provisions have been passed to ease restrictions and one to tighten restrictions on the amount of maquiladora output that could be sold in Mexico. While there are no hard figures on the results of these rule changes, reports of factory managers in Mexico suggest that virtually all production is still exported to the United States. See Wilson (1992, pp. 40-1). 


\section{ENDNOTES (Continued)}

\section{Note 15 continued}

The presence of non-U.S.-owned firms in the maquiladora industry has made it likely that some of the inputs imported by Mexico are from non-U.S. sources. In 1989, approximately 4 percent of maquiladoras were Japanese- or Korean-owned. Moreover, it is plausible that U.S.-owned firms also rely on inputs imported from non-U.S. sources. However, we do not know the extent of this non-U.S. sourcing. In vertical trade calculations for Mexico, the origin of the imported inputs does not matter; it matters only when we calculate the vertical trade share of total United States-Mexico trade.

16. Vertical trade $=\$ 3.6$ billion $+(\$ 3.6$ billion $) \times(.7 / .9) \times(.78 / .22)=$ $\$ 13.5$ billion. Total auto trade data are not yet available for 1995 .

17. The G-7 nations are Canada, France, Germany, Italy, Japan, the United Kingdom, and the United States.

18. In 1970, manufacturing accounted for about 60 percent of world merchandise trade; in 1996, it accounted for about 75 percent.

19. Italy is not shown on the chart because the OECD data had information only for 1985 .

20. We convert all countries' figures into 1989 dollars using 1989 exchange rates and the U.S. consumer price index. In several countries, vertical trade as a share of total trade declined between the next-to-last year and the last year. Most of the declines were relatively small, and none affects the underlying upward trends. By examining the data more carefully, we find that the largest decline, which occurred in the Netherlands between 1981 and 1986, is mainly explained by developments in the petroleum and coal products industry. The decline in oil prices between 1981 and 1986 would have lowered the share of imported inputs in gross output, reducing the estimated importance of vertical trade. Correlations presented below indicate that despite the decline, vertical trade as a share of total trade and trade as a share of gross output are highly correlated for all countries except Japan.
21. Some caution should be used in interpreting each correlation coefficient because there are only four or five data points for each country.

22. When we ran the regression in first differences and without the country dummies, we obtained similar coefficient estimates; also, the adjusted $\mathrm{R}^{2}$ was 0.35 .

23. The figures for Japan in the top and bottom halves of the table can be reconciled as follows: machinery vertical trade as a share of machinery trade grew, which made the fall in overall vertical trade as a share of total trade smaller, thereby contributing negatively to the (negative) growth.

24. These two forces have also facilitated specialization by allowing countries to take advantage of economies of scale. However, there is some disagreement about the relative importance of these two forces in explaining the growth of trade. See, for example, Rose (1991), Krugman (1995), and Bergstrand (1996).

\section{See Hummels (1997).}

26. Another factor that would favor vertical trade is the changing technology of goods production. Goods may require more production steps today than in the past: for example, the typical pharmaceutical drug needs fifteen or more production steps. The increase in the number of these steps heightens countries' opportunities to specialize in particular stages.

27. Ishii and Yi (1997) develop a model in which the gains from tariff reduction are several times larger when vertical specialization is included.

The views expressed in this article are those of the authors and do not necessarily reflect the position of the Federal Reserve Bank of New York or the Federal Reserve System. The Federal Reserve Bank of New York provides no warranty, express or implied, as to the accuracy, timeliness, completeness, merchantability, or fitness for any particular purpose of any information contained in documents produced and provided by the Federal Reserve Bank of New York in any form or manner whatsoever. 


\section{REFERENCES}

Balassa, Bela. 1967. TRADE LIBERALIZATION AMONG INDUSTRIAL COUNTRIES. New York: McGraw-Hill.

Beigie, Carl. 1970. THe CANADA-U.S. AutOmotive AgreEment. Quebec: Canadian American Committee.

Bergsten, C. Fred. 1997. “American Politics, Global Trade.” ECONOMIST, September 27, 23-6.

Bergstrand, Jeff. 1996. "The Growth of World Trade: Tariffs vs. Technology." Unpublished paper, University of Notre Dame, October.

Bhagwati, Jagdish. 1997. "Fast Track to Nowhere." ECONOMIST, October 18, 21-3.

Economic Council of Canada. 1975. LOOKING OUTWARD: A NeW TRADE STRATEGY FOR CANADA.

Hanson, Gordon H. 1996. "Localization Economies, Vertical Organization, and Trade." AMERICAN ECONOMIC REviEW 86, no. 5: 1266-78

Hufbauer, Gary C., and Jeffrey J. Schott. 1992. North AmeriCAN Free TRADE: ISsUES AND RECOMMENDATIONS. Washington, D.C.: Institute for International Economics.

Hummels, David. 1997. "Towards a Geography of Trade Costs." Unpublished paper, University of Chicago.

Irwin, Douglas A. 1996. "The United States in a New Global Economy? A Century's Perspective.” AMERICAN ECONOMIC Review 86, no. 2: $41-6$.

Isbii, Jun, and Kei-Mu Yi. 1997. "The Growth of World Trade." Federal Reserve Bank of New York Research Paper no. 9718, May.

Krugman, Paul R. 1995. "Growing World Trade: Causes and Consequences." BroOKINGS PAPERS ON ECONOMIC ACTIVITY, no. 1: 327-77.

Krugman, Paul R., and Maurice Obstfeld. 1997. INTERNATIONAL ECONOMICS: THEORY AND POLICY. 4th ed. New York: AddisonWesley.

Markusen, James R. 1997. "Trade Versus Investment Liberalization." Unpublished paper, University of Colorado, August.
Mataloni, Raymond, Jr., and Lee Goldberg. 1994. "Gross Product of U.S. Multinational Companies, 1977-91.” SURVEY OF CURRENT BusINESS, February: 42-63.

Rose, Andrew. 1991. "Why Has Trade Grown Faster than Income?" CANADIAN JOURNAL OF ECONOMICS 24, no. 2: 417-27.

Sanyal, Kalyan K., and Ronald W. Jones. 1982. "The Theory of Trade in Middle Products." American ECONOMIC Review 72, no. 1: 16-31.

United Nations Conference on Trade and Development. 1996. WORLD INVESTMENT REPORT, 1996: INVESTMENT, TRADE AND INTERNATIONAL POLICY ARRANGEMENTS. New York: United Nations.

United Nations Statistical Division. 1994. INTERNATIONAL TRADE Statistics Yearbook. Vol. 1, Trade by Country. New York: United Nations.

U.S. Department of Commerce. Bureau of Economic Analysis. 1994-96. Survey OF CURRENT Business. Various issues. Washington, D.C.: U.S. Government Printing Office.

Ward's Communications, Inc. 1969-96. WARD's AUTOMOTIVE YEARBOOK. 31st-58th eds.

Wells, Louis T. 1993. "Mobile Exporters: New Foreign Investors in East Asia.” In K.A. Froot, ed., Foreign Direct Investment. Chicago: University of Chicago Press.

Wilson, Patricia A. 1992. EXPORTS AND LOCAL DEVELOPMENT: Mexico's New Maquiladoras. Austin: University of Texas Press.

Wonnacott, Ronald, and Paul Wonnacott. 1967. Free TRADE BeTWEEN the United States and Canada: The Potential EConomic EFFECTS. Cambridge: Harvard University Press.

Zeile, William J. 1993. "Merchandise Trade of U.S. Affiliates of Foreign Companies." Survey OF CuRRENT BuSINESS, October: 52-65.

1995. "Foreign Direct Investment in the United States." SURVEY OF CURRENT BusINESS, May: 57-81. 